\section{GM Nation? Debate}

J Jacoby

Heredity (2004) 92, 135. doi:10.1038/sj.hdy.6800421

In September 2003, the UK published the results of an unprecedented national debate on GM issues, 'GM Nation?' to help guide the Government's consideration for potentially adopting the applications of this technology. Some believe it was just a PR exercise, but the unequivocal message emerging from the debate is of overwhelming public uncertainty. The report revealed that questions abound over the safety of GM food, the environmental impact of growing GM crops, and where the public can get hold of trusted, nonpartisan information.

People understand the potential uses of GM but want to comprehend the issues better in order to have informed opinions. However, far from information quelling people's fears, many become more concerned as they engage in GM issues. Furthermore, there is an increasing mistrust of multinational companies and the possibility of early commercialisation of a little-understood technology.

The UK's report has caused a stir in Europe, where Green Party MEP Dr Caroline Lucas claimed that the European Parliament's Environmental Committee has admitted 'for the first time the possibility of a GM-free UK'. Outside of Europe, the use of GM crops in developing countries is a further concern.

Opinion is clearly still divided, not just in the public domain, but also through the scientific community. Here, Heredity presents two different views, written by eminent scientists involved in the GM field.

\author{
J Jacoby \\ Nature Publishing Group \\ E-mail: j.jacoby@nature.com
} \section{Gim Debate: Dispelling myths} C Lichtenstein

Heredity (2004) 92, 135-136. doi:10.1038/sj.hdy.6800422

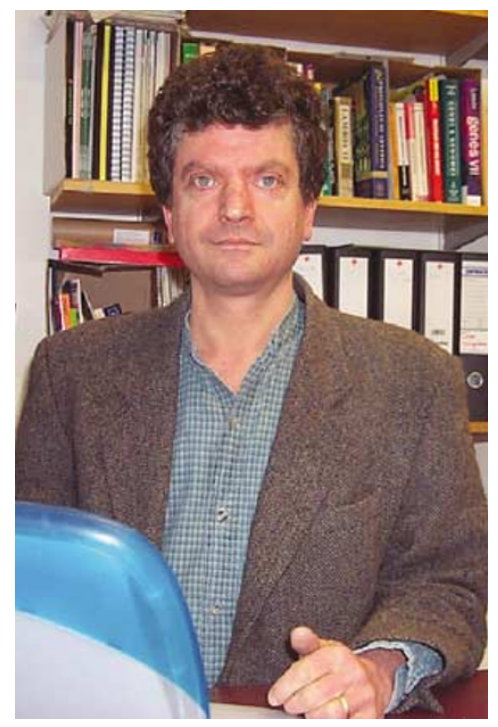

1 participated in a number of 'GM Nation?' debates in the early summer of 2003, both as a plant molecular biologist with relevant research interests, and as a panel member of Cropgen (www.cropgen.org). Cropgen is a consumer and media information initiative that makes the case for GM crops, helping to achieve a greater measure of realism and balance in the GM debate that has been running these last few years.

Attendees at the debates I spoke at were largely anti-GM; thus it is not surprising that the government report, which summarised the 37000 questionnaires returned from the 675 meetings held across the country, found antipathy to GM to be at odds with other polls of the population as a whole. A number of other flaws in the analysis were recently shown by Campbell and Townsend (2003). Nonetheless, the outcome of 'GM Nation?' still puts the government in an awkward position in deciding on the future of GM in Britain.

The debates covered a complex web of inter-related issues: (i) alien, unnatural technology; (ii) food safety; (iii) intensification of agriculture and its effect on the environment; (iv) genetic pollution; (v) being driven solely by profits.

As a scientist, I saw the anti-GM 'scientists' as my principal adversaries, who sought to use their scientific credentials to incite fear in the hearts of the scientifically ignorant with a series of wild statements about the dangers of GM. Yet when challenged, they were unable to supply any peerreviewed research as evidence to support them.

It was on the first issue of 'alien unnatural technology' that I first became engaged in the GM debate back in 1999: I led a project to engineer transgenic virus-resistant plants by expressing a virally derived antisense transgene that blocked expression of the invading viral DNA replication machinery (Day et al, 1991). Tobacco was our original chosen plant model for engineering plant resistance, and we found that similar 'transgenes' were already present as multiple repeats of methylated silent DNA on two different tobacco chromosomes (Bejarano et al, 1996), as well as related species, suggesting an ancient illegitimate viral DNA recombination event 25 million years ago (Murad et al, 2004 and references therein). So, GM can happen in nature, I argued, using this as an illustration because of the poignancy of it being the same transgene that Mother Nature had 'used'. However, I made the general point that horizontal gene transfer is natural - the real driver being selection - citing the spread of antibiotic-resistance genes in bacterial pathogens by artificial selection on natural plasmid- and transposon-mediated gene transfer.

Of course, all of agriculture is alien and unnatural and selective breeding is artificial selection. What GM adds is artificial variation in place of selection 
based on variation arising from random natural mutations or, since the 1960s, from randomly induced variation using gamma rays: the so-called 'mutation breeding'.

Conventional agriculture is now more productive than ever, with its new crop varieties, the green revolution, and the use of fertilisers, herbicides, and pesticides. This reduces biodiversity in the crop field, but allows us to feed more people, more cheaply, and leaves more land free of cultivation.

Organic farming is less productive and requires more land, but GM technology offers organic farmers the opportunity to increase their productivity organically, that is without the need to spray pesticides. Future benefits include crop production on marginal lands, high in salt or low in water. Thus the rejection of GM, an intrinsically organic process, by the organic movement is puzzling. They are biting the very hand that could feed them.

I heard an anti-GM scientist say that GM foods cause cancer, that the herbicide 'round-up' used both generally and on the herbicide-tolerant GM crops in the recent farm-scale evaluations, causes neurodegenerative diseases, yet no evidence was presented to support these claims. In any case, GM is a process and not a product, so no generic statement is possible on the safety of GM food unless we accept the flawed and controversial data that Pusztai presented in the Lancet some years ago, that the process ws mysteriously able to make food harmful (Ewen and Pusztai, 1999).

An anti-GM scientist told us that GM technology was unstable and unreliable, could cause mutations by inserting into genes, and that GM transgenes were prone to methylation. It was not made clear why this was a problem for anyone but the breeder, who might need to screen a number of transgenic lines for their desired characteristics. The argument was eclectic in failing to point out that mutation breeding, perhaps to a even greater extent than GM, causes random unknown DNA damage, yet $70 \%$ of crop varieties currently in use, including those by organic farmers, were made by this method.

However, this argument generated the fear that these transgenes could run amok and, due to their instability, leave the host plant escaping into the wild. There was much vivid imagery and emotive language but no clear mechanism to account for how such events might occur, nor for the implication that 'GM DNA' was more dangerous to eat than any of the other vast quantities of DNA that we eat every day.

Unsubstantiated claims by the fearmongering anti-GM scientists highlight a central problem in a high technology society of specialists: few, if any, of these anti-GM scientists are currently, or have ever been, actively engaged in experimental research relevant to GM. Such research could cover the regulation of gene expression; epigenetics and gene methylation; DNA recombination; and construction and screening of transgenic plants. No editor of a scientific journal would choose these individuals as a reviewer. However, how is the layperson to evaluate the credentials of these experts who present themselves to the media? Society does currently seem to be moving in the wrong direction: a distrust of mainstream 'conventional science' in favour of the fringe.

The challenge we face in countering the anti-GM scientists is to reduce complex scientific principles to persuasive and understandable morsels for the layperson, in the face of quasiscientific scare-mongering. One's immediate instincts are to rebut with a reasoned, coherent scientific argument that invalidates this techno-babble; the danger exists, however, that only a scientist would realise the strength of your argument, and that the lay audience is left as frightened as before. Scare-mongers can use science to promote fear far more easily than scientists can use science to reduce anxiety. Twas ever thus.

Among all this, what most worried people at these debates was capitalism. There were conspiracy theories that GM technology, driven solely by profits, was leading to global control of food production by large multinational companies in collusion with governments, thus exploiting poor farmers with expensive GM seed and doing nothing for the needs of the developing world. Yet, with the collapse of communism, this grievance against capitalism was not countered by any presentation of an alternative.

With no training in economics, I found myself having to defend capitalism by quoting from The Wealth of Nations by Adam Smith: 'It is not from benevolence of the butcher, the brewer, or the baker, that we expect our dinner, but from their regard to their own interest...(Man is) led by an invisible hand to promote an end which was no part his intention..." I pointed out that all economies need industry to be profitable; that industry has to operate with profit in mind; that we all have a stake in this profit as holders of ISAs and pension funds; that new technologies increase capital value and benefit the whole of society, without stealing from the poor to give to the rich: and that if capitalism really was their concern, there were far bigger fish to fry than GM.

Conrad Lichtenstein, Professor of Molecular Biology at the University of London's Queen Mary and Westfield College, was among the first to use RNA silencing to engineer resistance to viral infection in GM plants. He was the first to show viral integration into plant genomes during evolution and is heavily involved in the public understanding of science within the GM debate.

Bejarano ER, Khashoggi A, Witty M, Lichtenstein CP (1996). Integration of multiple repeats of geminiviral DNA into the nuclear genome of tobacco during evolution. Proc Natl Acad Sci USA 93: 759-764.

Campbell S, Townsend E (2003). Flaws undermine resuts of UK biotech debate. Nature 425: 559 .

Day AG, Bejarano E, Buck KW, Burrell M, Lichtenstein CP (1991). Expression of an antisense viral gene in transgenic tobacco confers resistance to the DNA virus tomato golden mosaic virus. Proc Natl Acad Sci USA 88: 67116715.

Ewen SWB, Pusztai A (1999). Effect of diets containing genetically modified potatoes expressing Galanthus nivalis lectin on rat small intestine. Lancet 354: 1353-1354.

Murad M, Bielawski J, Lim Y, Matyasek R, Kovarik A, Nichols RA, Leitch AR, Lichtenstein CP (2004). The origin and evolution of geminivirus-related DNA sequences in Nicotiana. Heredity (in press). 